\title{
Cytotoxic effect of Ficus religiosa and Ficus benghalensis latex extracts on MCF-7 cell line
}

\author{
CDSLN Tulasi ${ }^{1}$, M. Lakshmi Narasu ${ }^{2}$, L. Saida ${ }^{3 *}$ \\ ${ }^{1,2,3}$ Centre for Biotechnology, Institute of Science and Technology, Jawaharlal Nehru Technological Institute, Hyderabad, \\ Telangana -84 . \\ *Corresponding author: yrvlm.chidepudi@gmail.com, Phone: +918897703221
}

Available online at: www.isroset.org

Received: 02/Nov/2018, Accepted: 26/Nov/2018, Online: 31/Dec/2018

\begin{abstract}
Plants from Ficus genus were selected for the present study to screen their cytotoxic activity against the chosen human breast cancer cell line MCF-7. Cells were seeded in the 96 well plate and were grown for 24 hrs ensuring the proper attachment and adequate growth of cells in each well, after which the plant solvent extracts were treated in five different concentration for $24 \mathrm{hrs}$ and triplicates were maintained. The evaluation was based on reduction of MTT (3- [4,5dimethylthiazol-2-yl]-2,5-diphenyl tetrazolium bromide) by mitochondrial dehydrogenase of viable cells, which gives a blue coloured formazan product, measured by spectrophotometry and the percentage growth inhibition as well the concentration at which the cells were $50 \%$ viable $\left(\mathrm{IC}_{50}\right)$ was calculated. The morphological changes at $\mathrm{IC}_{50}$ were taken photographs.
\end{abstract}

Keywords-Ficus benghalensis, Ficus religiosa, cytotoxic activity, MTT, IC50, Morphological changes

\section{INTRODUCTION}

Cancer is the abnormal growth of the tissue because of lack of regulation in cell division process. More or less 200 different types of cells in the body were affected with this ailment. Over $50 \%$ of drugs isolated from herbal plants with therapeutic activity were under clinical trials for anti cancer activity [1]. Many biological, epidemiological and clinical studies $[2,3,4,5,6,7,8]$ confer a strong correlation between dietary habits and lower chance of cancer development. Numerous studies indicated that in many types of cancel cells, dietary agents would induce apoptosis and cell cycle arrest without affecting the normal cells $[9,10]$.

Medicinal plants being an effective source of both traditional and modern medicines are genuinely useful for primary health care. Ficus religiosa. L. and Ficus benghalensis. L belongs to the family Moraceae, has many medicinal properties. The barks have been used for diarrhoea, dysentery, leucorrhea, menorrhagia, for vaginal and other urogential disorders. Some reported pharmacological activity of $F$. religiosa like fruit extracts exhibited antitumor activity in the potato disc bioassay [11] Aqueous extract showed high antimicrobial activity against selected pathogenic like $B$. subtilis and P. aeruginosa [12]. So it may have antioxidant potential. An antioxidant is a molecule that slows or prevents the oxidation of the molecules. Antioxidants terminate these chain reactions by removing free radical intermediates and inhibit other oxidation reactions by being oxidized themselves. As a result, antioxidants are often considered as reducing agents such as thiols, ascorbic acid, polyphenols [13]. The methanolic extract of figs (fruits) of Ficus religiosa had anticonvulsant activity [14]. Anti inflammatory and analgesic effect of aqueous and methanolic bark extract of Ficus benghalensis has been evaluated. The methanolic extract shows significant anti-inflammatory potential as compared to the aqueous extract. $[15,16]$ Thus, Ficus species are rich source of naturally occurring antioxidants of which phenolic compounds and flavonoids play a vital role in preventing innumerable health disorders related to oxidative stress including cardiovascular diseases, neurodegenerative diseases and cancer. Ficus species due to their strong antioxidant and biological properties are also known to diffuse the toxic free radical and can be used as a possible food additive or in nutraceutical and biopharmaceutical industries [17].

In the present study, the cytotoxic activity of Ficus religiosa and Ficus benghalensis solvent extracts was screened against MCF-7 cell line in-vitro and the 50\% inhibitory concentration $\left(\mathrm{IC}_{50}\right)$ was calculated and represented. The study was designed to examine the cytotoxic effect on plant extract on inhibiting the further proliferation of cancer cell line.

\section{MATERIALS AND METHODS}

\section{Collection of plant material:}

Ficus benghalensis and Ficus religiosa latex, the milky white substance, which turns yellow on standing, was collected into a clean container, from the tree trunk portion by peeling off 
the bark, during the early hours of the day. Dried latex was then ground to powder and stored in dry airtight containers for the further experimental analysis. Authentication of the plant material was done at Department of Botany, Andhra University, Visakhapatnam, Andhra Pradesh as the plant material was collected from university during fruiting season and deposited in the botany department herbarium.

\section{Extraction:}

The latex was dried at $50^{\circ} \mathrm{C}$, powdered and extracted by methods corresponding to the extraction protocols used for natural compounds. The solvents used for extraction were ethyl acetate, acetone, ethanol and methanol according to the increasing polarity. The ground plant material was percolated with respective solvent in 10:1 (w/v) for $72 \mathrm{hrs}$ placed in shaking incubator at 240rpm (JS Research, JSSi-300C, Korean), then concentrated to dryness under reduced pressure. The obtained extract was dissolved in DMSO to form concentration of $50 \mathrm{mg} / \mathrm{ml}$, which was filter sterilized before checking its cytotoxic potency.

\section{In vitro assay for cytotoxic activity Cell culture}

Cancer cell line selected for the present study was human Breast cancer (MCF-7) procured from NCCS, Pune. The cells were maintained in RPMI 1640 medium supplemented with $10 \%$ fetal bovine serum, $1 \% 2 \mathrm{mM}$ L-glutamine, $100 \mathrm{IU} / \mathrm{ml}$ penicillin and $100 \mu \mathrm{g} / \mathrm{ml}$ streptomycin maintained at $37^{\circ} \mathrm{C}$ in humidified incubator with $5 \% \quad \mathrm{CO}_{2}$. According to their growth rates, the optimum plating density of each cell line was determined to be $5-6 \times 10^{3}$ cells/ well in 96 well microtiter plate to maintain exponential growth through out the experiment.

\section{Cytotoxicity assay}

For the assay, cells were washed with phosphate buffer saline (PBS), treated with $0.025 \%$ trypsin-EDTA (Sigma) $(200 \mu \mathrm{l})$ and flushed with medium $(2 \mathrm{ml})$ for the uniform cell detachment from the T-flask. The cell suspension with all the viable cells were counted by typhan blue exclusion using a haemocytometer and then diluted with medium to give the previously determined cell-density $\left(5-6 \times 10^{3}\right.$ cells/ well $)$. The cells were then seeded by adding $100 \mu \mathrm{l} /$ well of diluted cell suspension to the 96 well microtiter plate and incubated at $37^{\circ} \mathrm{C}$ for $24 \mathrm{hrs}$ ensuring proper and uniform cell attachment to the bottom of the plate. After incubation period the cells were treated with extracts which were already dissolved in DMSO stock. The latex extracts were further diluted with medium to make 5 different concentrations. $100 \mu \mathrm{l}$ of each concentration was loaded in the well in triplicates. Positive control, Doxorubicin was used at concentrations $0.25 \mu \mathrm{g} / \mathrm{ml}$, $0.5 \mu \mathrm{g} / \mathrm{ml}, 0,75 \mu \mathrm{g} / \mathrm{ml}, 1 \mu \mathrm{g} / \mathrm{ml}$ and $1.5 \mu \mathrm{g} / \mathrm{ml}$. The final dilution used for treating cells was made up to $0.4 \%$ of the initial solvent which was used as negative control. The plates were incubated for $24 \mathrm{hrs}$. Cell viability was assessed with MTT dye reduction assay with minor modifications [18, 19].
The cytotoxic activity of latex extract was calculated as percentage of cell growth inhibition by using following formula:

$\%$ Growth inhibition $(\%)=\left[\left(\mathrm{A}_{\text {Control }}-\mathrm{A}_{\text {Sample }}\right) / \mathrm{A}_{\text {Control }}\right] \times 100$ Where $\mathrm{A}_{\text {control }}$ indicates the absorbance of control containing $0.5 \%$ Ethanol-ethyl acetate mixture. A Aample is the absorbance of treated cells at different concentration. $\mathrm{IC}_{50}$ values (the concentration of sample required for inhibition of $50 \%$ of cell growth) were obtained from the regression line.

\section{Visualization of cells' Morphological changes under light microscope}

The effect of latex solvent extracts on the morphology of cells after treating and incubation for $24 \mathrm{hrs}$ was visualized under Olympus IX71 phase contrast light microscope. The consumed medium was removed, PBS was added and the cells were observed and photographed with Olympus camera attached to the microscope.

\section{Statistical analysis}

Values were expressed as mean \pm standard deviation (SD) where $n=3$ for MTT assay. The values were exported to excel sheet and the IC 50 values were calculated using regression line plot with $\mathrm{R}$ squared value, which determines the variability of response data around its mean value.

\section{RESULTS AND DISCUSSION}

\section{Cytotoxic activity on cell lines}

The anti proliferative effect of $F$. benghalensis and $F$. religiosa solvent extracts on MCF-7 was observed with MTT assay. The percentage growth inhibition of the cancer cells was observed in a dose dependent manner where $90 \%$ inhibition was found at highest concentration, $200 \mu \mathrm{g} / \mathrm{ml}$. The $\mathrm{IC}_{50}$ values which is the $50 \%$ inhibition of cell proliferation, were calculated from the basic graphing in Microsoft excel (Table 1). Ethanolic extract has shown potent cytotoxic activity against MCF-7 with $\mathrm{IC}_{50}(101.55 \pm 0.94 \mu \mathrm{g} / \mathrm{ml})$ and $\mathrm{IC}_{50}(72.06 \pm 3.9 \mu \mathrm{g} / \mathrm{ml})$ in case of $F$. benghalensis and $F$. religiosa respectively. The positive control, Doxorubicin has shown its potency against the cell lines chosen for the present study (Fig 1). The Ficus extract has shown best potency against breast cancer cell line.

The previous studies reported that the crude extract of plants have more cytotoxic activity than their isolate compounds because of the synergistic effect of all the phytochemicals present in the plant $[20,21]$. According to the standards of the National Cancer Institute (NCI), a crude extract may be considered as active for an $\mathrm{IC}_{50} \leq 20 \mu \mathrm{g} / \mathrm{ml}$ [22]. The reduction of MTT by viable cells in culture is a method widely recommended for examining the cytotoxic effect of xenobiotic, assessing proliferation rates, and analyzing cell activity [23, 24]. MTT is reduced inside viable cells to waterinsoluble purple-colored formazan by mitochondrial dehydrogenases, although in various cell lines over $50 \%$ of 
the dye penetrating the cell membrane can be reduced by non mitochondrial, cytosolic, and microsomal enzymes [25,26].

\section{CONCLUSION AND FUTURE SCOPE}

In summary, both the Ficus plant extracts investigated in the study seem to possess a potential cytotoxic activity. The future studies will investigate in greater detail the action of Ficus substances, and synthesize new and possibly more active derivatives for their pharmaceutical application.

Table 1: $\mathrm{IC}_{50}(\mu \mathrm{g} / \mathrm{ml})$ values of latex extracts on human cancer cell lines.

\begin{tabular}{|l|l|l|l|}
\hline S.No & Plant & Solvent Extracts & $\mathbf{I C}_{\mathbf{5 0}}$ Value $(\boldsymbol{\mu g} / \mathbf{m l})$ \\
\hline \multirow{3}{*}{} & \multirow{2}{*}{ Ficus benghalensis } & Ethanol & $\mathbf{1 0 1 . 5 5} \pm \mathbf{0 . 9 4}$ \\
\cline { 3 - 4 } & & Methanol & $151.12 \pm 2.34$ \\
\cline { 3 - 4 } & & Acetone & $120.20 \pm 1.25$ \\
\cline { 3 - 4 } & & Ethyl Acetate & $175.12 \pm 1.43$ \\
\hline \multirow{2}{*}{} & \multirow{2}{*}{ Ficus religiosa } & Ethanol & $149.95 \pm 5.5$ \\
\cline { 3 - 4 } & & Methanol & $\mathbf{7 2 . 0 6} \pm \mathbf{3 . 9}$ \\
\cline { 3 - 4 } & & Acetone & $163.65 \pm 0.78$ \\
\cline { 3 - 4 } & & Ethyl Acetate & $90.98 \pm 1.2$ \\
\hline 3 & \multicolumn{2}{|l}{ Doxorubicin } & $1.23 \pm 0.9$ \\
\hline
\end{tabular}

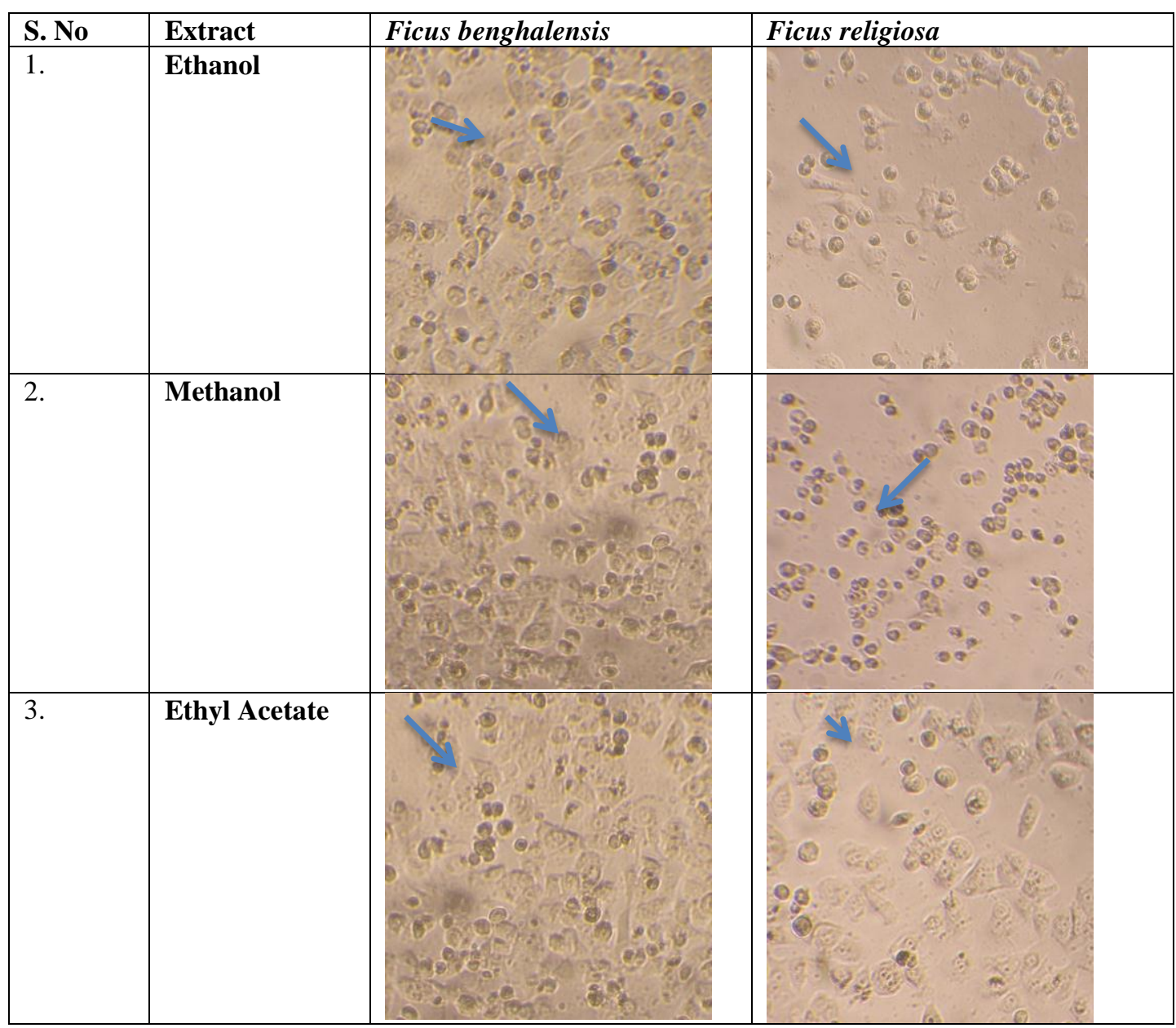




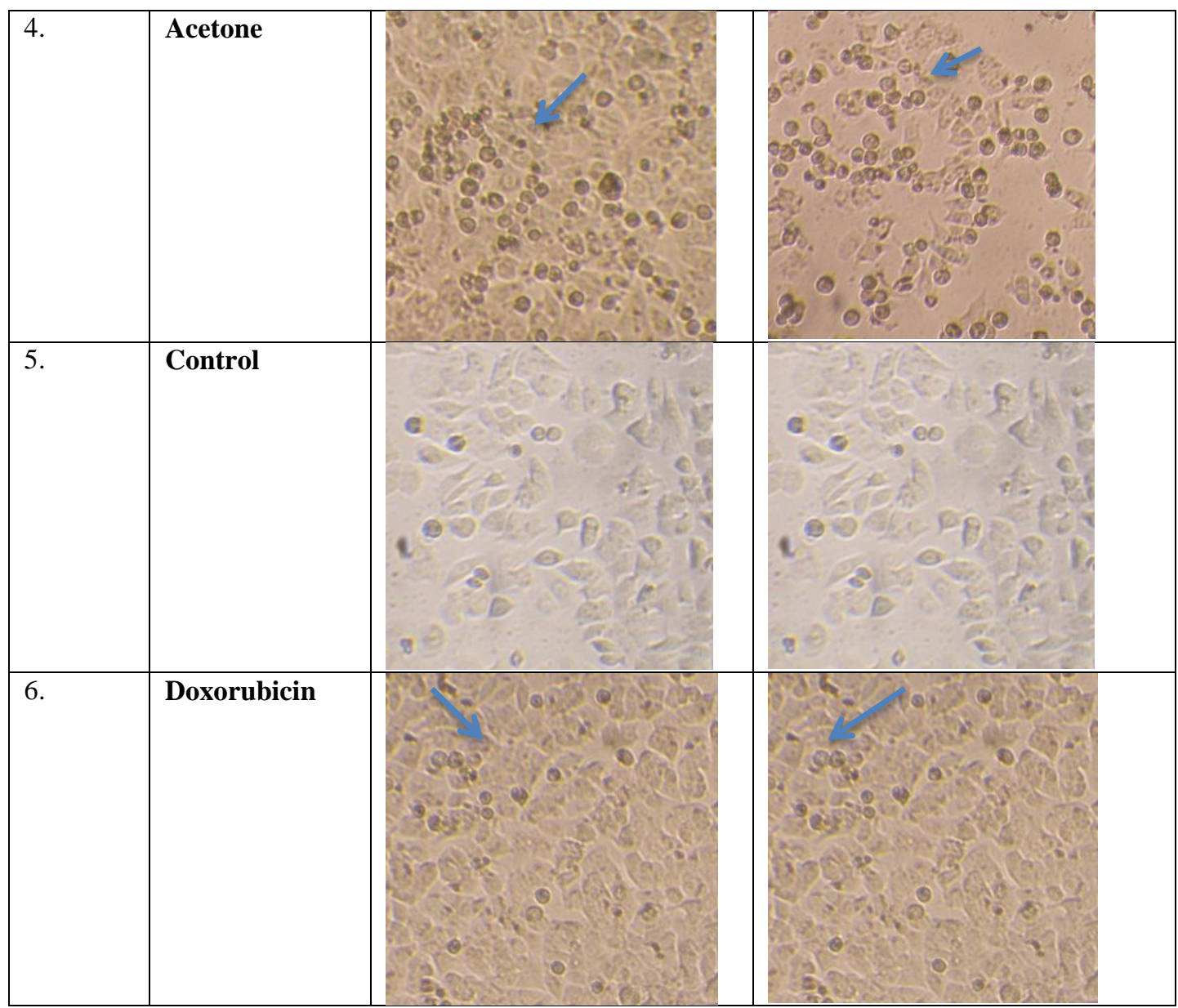

Fig 1: Morphological changes at IC ${ }_{50}$ against all the selected cell lines

\section{ACKNOWLEDGEMENTS}

The authors are grateful to Centre for Biotechnology, Institute of Science and Technology, Jawaharlal Nehru Technological University, Hyderabad for providing bench space to carry out the experimental work.

\section{AUTHORS CONTRIBUTION}

CDSLNT conducted the complete experimental work, compiled the data, pictures and prepared the manuscript. MLN and LS designed as well guided the work.

\section{REFERENCES:}

[1] Cragg, Gordon M., and David J. Newman, Antineoplastic agents from natural sources: achievements and future directions Expert Opin Investig Drugs; 9: 2783-2797, 2000

[2] American Cancer Society, Cancer Facts \& Figures. American Cancer Society, Inc., GA 2010.

[3] Amin, Amr, and Mohamed Mousa, Merits of anti-cancer plants from the Arabian Gulf region Cancer Ther.; 5: 55-66, 2007.
[4] Anand, Preetha, Chitra Sundaram, Sonia Jhurani, Ajaikumar B. Kunnumakkara, and Bharat B. Aggarwal, Curcumin and cancer: an "old-age" disease with an "age-old" solution Cancer lett.; 267: 133-164, 2008.

[5] Campbell, Cheryl T., Misty Prince, Greg M. Landry, Victor Kha, and Heather E. Kleiner, Pro-apoptotic effects of $1^{\prime}$ acetoxychavicol acetate in human breast carcinoma cells Toxicol. Lett.; 173: 151-160, 2007.

[6] Cao, Peng, Xueting Cai, Wuguang Lu, Fei Zhou, and Jiege Huo. Growth Inhibition and Induction of Apoptosis in SHG-44 Glioma Cells by Chinese Medicine Formula "Pingliu Keli Evid Based Complement Alternat Med. 2011; 958243. http://doi.org/10.1155/2011/958243

[7] Conforti, F., G. Ioele, G. A. Statti, M. Marrelli, G. Ragno, and F. Menichini, Antiproliferative activity against human tumor cell lines and toxicity test on Mediterranean dietary plants Food chem. Toxicol; 46: 3325-3332, 2008.

[8] Conforti, Filomena, Silvio Sosa, Mariangela Marrelli, Federica Menichini, Giancarlo A. Statti, Dimitar Uzunov, Aurelia Tubaro, and Francesco Menichini, The protective ability of Mediterranean dietary plants against the oxidative damage: the role of radical oxygen species in inflammation and the polyphenol, flavonoid and sterol contents Food Chem.; 112: 587-594, 2009.

[9] Berquin, Isabelle M., Iris J. Edwards, and Yong Q. Chen. Multitargeted therapy of cancer by omega-3 fatty acids Cancer lett.; 269: 363-377, 2008. 
[10] Czene, Stefan, Elisabetta Testa, Jonas Nygren, Igor Belyaev, and Mats Harms-Ringdahl. DNA fragmentation and morphological changes in apoptotic human lymphocytes Biochem. Biophys. Res. Commun,; 294: 872-878, 2002.

[11] Mousa O, Vuorela P, Kiviranta J, Wahab SA, Hiltohen R, Vuorela H. Bioactivity of certain Egyptian Ficus species. J Ethnopharmacol; 41:71- 6, 1994.

[12] Preethi R., Vimal V. Devanathan and Loganathan M. Antimicrobial and Antioxidant Efficacy of Some Medicinal Plants against Food Borne Pathogens. Adv Biol Res; 4 (2): 122-5, 2010.

[13] Sies.H. Oxidative stress : Oxidants and antioxidants. ExpPhysiol;82(2):291- 5, 1997.

[14] Damanpreet Singh, Rajesh Kumar Goel. Anti convulsant effect of Ficus religiosa: Role of serotonergic pathways. J Ethnopharmacol June; 123(2):330- 4, 2009.

[15] Vishnu.N.Thakare, Anupama.A.Suralkar, Avinash.D.Deshpande, Suresh.R.Naik. Stem bark extraction of Ficus bengalensis Linn for anti inflammatory and analgesic activity in animal models Indian J Exp Biol; 48:39-45, 2010.

[16] Patil.V. V., Pimprikar.R.B., Patil.V.R. Pharmacognostical studies and evaluation of anti-inflammatory activity of Ficus bengalensis Linn. J Pharm; 1: 49-53, 2009.

[17] Sirisha. N, Sreenivasulu .M, Sangeeta .K, Madhusudhana Chetty . C. Antioxidant Properties of Ficus Species - A Review. Int J PharmTech Res.; 2(4): 2174-82, 2010.

[18] T. Mosmann. Rapid colorimetric assay for cellular growth and survival: application to proliferation and cytotoxicity assays $\mathrm{J}$. Immunol. Meth.; 65: 55, 1983.

[19] S.M. Konstantinov, H. Eibl, M.R. Berger. BCR- ABL influences the antileukaemic efficacy of alkylphosphocholines. British J. Haematol.,; 107: 365, 1999

[20] Hamburger M., Hostettmann K. Phytochemistry, 30, 3864-3874,
1991.

[21] Ramaiah Maddi, Venkata Lakshmi Kandula, Bhagyavathi Vallepu, Hymavathi Navuluri, Harshavardhan Kollu, "Preliminary Phytochemical Analysis and Invitro Anti-viral Activity of Ethanolic extract of Whole plant of Tinospora cordifolia (Thunb.) Miers against Hepatitis-A Virus", International Journal of Scientific Research in Biological Sciences, Vol.5, Issue.3, pp.51-55, 2018

[22] Cordell GA, Kinghorn D, Pezzuto JM, Separation, structure elucidation, and bioassay of cytotoxic natural products, in Colegate SM, Molyneux RJ (eds): Bioactive natural products. Boca raton, CRC Press, pp 195-216, 1993.

[23] Denizot F., Lang R. Rapid colorimetric assay for cell growth and survival. Modifications to the tetrazolinum dye procedure giving improved sensitivity and reliability. J Immunol. Methods; 83: 271-277, 1986.

[24] Mosmann T. Rapid colorimetric assay for cellular growth and survival: Application to proliferation and cytotoxicity assays. J Immunol. Methods; 65: 55-63, 1983.

[25] Collier A.C., Pritsos Ch.A. The mitochondrial uncoupler dicumarol disrupts the MTT assay. Biochem Pharmacol.; 66: 281287, 2003.

[26] Gonzalez R.J., Tarloff J.B. Evaluation of hepatic subcellular fraction for alamar blue and MTT reductase activity. Toxicol in Vitro; 15: 257-259, 2001 